\title{
The Implementation of Integrated Technology in Motivating Students of an Accelerated Program at Senior Secondary School Makassar, Indonesia
}

\author{
Muhammad Irfan Rahim \\ Kisman Salija \\ Sukardi Weda \\ muhammadirfanrahim@gmail.com
}

State University of Makassar, Indonesia

\begin{abstract}
The objectives of this research are to find out: (1) the description of the implementation of integrated technology in an accelerated program in motivating the students in Makassar senior secondary school, (2) the description of how the teacher maintains the motivation of students through integrated technology at accelerated program in Makassar senior secondary school, and (3) the description of the students' responses to the implementation of integrated technology in an accelerated program in motivating the students in Makassar senior secondary school.This research is qualitative research which done in SMAN 17 Makassar. The participants of this research were a teacher and students of an accelerated program. To collect the data, the researcher used recording and interview with the teachers and students. In analysing the data, the researcher used qualitative method. The findings of this research described (1) The implementation of integrated technology at the accelerated program in SMAN 17 Makassar can be described under several categories: kinds of technology used by the teacher, kinds of application or program used by the teacher, the function of technology, the teacher's ways to teach by using technology, the teacher's experience in achieving the technology used, the technology facilitation provided in technology integration, the teacher's ways in teaching English skills, the use of social media in teaching and learning, the reason of choosing E-Mail, the teacher's ways to minimize unexpected problem along the use of technology, and the technology influence toward student's motivation (2) The teacher's ways to maintain the students' motivation by using integrated technology can be described two some categories: the reasons underlying the importance of technology and the teacher's ways of indicating and maintaining the students' motivation. (3) Students' responses toward the integrated technology could be stated in positive way, they liked it, they were interested, and they preferred studying by using technology.
\end{abstract}

Keyword: Integrated Technology and Students' Motivation

\section{INTRODUCTION}

English was considered as the first foreign language and taught formally from elementary school up to the university level in Indonesia. Therefore the role of the teacher was often formal and ongoing, carried out by way of occupation or profession at a school or other places of formal education. 
Umayanti (2012) reveals that English as an international language and it was very important and had many interrelationships with various aspects of life owned by human being. In addition, Harmer (1991:45) states that a teacher should do his functions and his roles during the teaching and learning process in order to benefit his students and attract them to learn.

Regarding with it Eggen and Kauchak (2002) reveal that technology can heighten learners' motivation by increasing self-efficacy and selfesteem, improving students' attendance, promoting more positive attitudes toward school and more enjoyment of out-of-class activities, and increasing students involvement in learning activities. Technology was unique in its ability to increase learners' sense of efficiency. We can conclude that students with high intelligence need special attention in order to achieve maximum achievement in their learning process. Accelerated class needed not only curriculum improvement, but also other aspects that should be dealt with students' learning environment. Teaching strategy was one factor that can determine the quality of accelerated classes. Integrated technology as a strategy to reach the goal of the teaching and learning process and motivate them to learn English.

\section{LITERATURE REVIEW Definition of Integrated Technology}

According to the National Forum on Educational Statistics (NFES) (1998), integrated technology is the incorporation of technology resources and technology-based practices into the daily routines, work, and management of schools. Technology resources include computers and specialized software, network-based communication systems, and other equipment and infrastructure. Weston (2005) defines integrated technology as sustained and meaningful use of an application for the core function of class instruction or learning.

\section{Definition of Motivation}

According to Dornyei (2001), motivation is a force that cannot be seen or it is an abstract and a hypothesis which used to explain humans' behavior. Motivation is also related directly to human's mind which is correlated to wants or desires not humans' feelings.

Motivation includes many things, for example, the effort expanding, the desire to learn and positive thinking about language learning (Gardner, 1985a, 1958b as cited in Wesley, 2009, p.271).

Fredricks (2004) states that motivation is something that energizes, directs, and sustains behavior, it gets students moving, points them in a particular direction, and keeps them going. 


\section{Some Concepts of Accelerated Program}

Wlodkowski (2003) in Boyd (2005) defines accelerated class program as program structured to enable students to take courses and earn credits in shorter period of time than would occur in traditional semester long course. From that expert's idea, we can say that through accelerated class program, students are able to finish their study in shorter period.

\section{METHOD}

This research employed qualitative research design. An EFL teacher and 20students as the participants of this research were chosen by using purposive sampling. This research applied two kinds of instrument namely classroom observation and interview. The data were collected in some steps namely knowing the schedule, observing the teaching and learning process, interview the students and interview the teacher. Furthermore, in analyzing data from classroom observation and interview, the researcher used qualitative data analysis based on Creswell and Miller (2000), which stated that a validity procedure where researchers search for convergence among multiple and different sources of information to form themes or categories in a study.

\section{FINDINGS ANDDISCUSSION Findings}

The result of the observation conducted for four meetings revealed that the implementation of technology at SMAN 17 Makassar showed the benefit of using technology integration based on the following concept;

1. The implementation of integrated technology at an accelerated program in motivating the students in Makassar senior secondary school.

The implementation of technology integration in teaching and learning process can be seen from some aspects.

\section{a. The Knowledge and Skills of Computer Use 1). Teacher's Response}

Based on the researcher's observation, the teacher and the students at accelerated program had knowledge and skill of computer use.

The teacher brought her own computer and operated it by herself during the teaching and learning process. All students had had a computer device since they are a junior high school student and most of them completed their task by using computer. 
Their responses showed that most of them had knowledge of word processing, use of Internet, Microsoft Excel, e-mailing and PowerPoint. Students ensured that they had knowledge of searching for information which presupposed knowledge of using search engines like Google. Although the researcher had not asked students to indicate where they had acquired the knowledge of computer use, some students went further and mentioned where they had acquired that knowledge. For example, students indicated that they had acquired their computer knowledge from the courses that were offered by course knowledge, extracurricular when they were in junior high school student or by their own learning experience.

\section{a) Kinds of technology used by the teacher.}

The teacher was asked about the kinds of technology that she used in English teaching and learning process. The answer indicated the various technologies used by the teacher described that the teacher has mastered the technology use. It indicated that the teacher could operate technology and used it in teaching learning process and she was able to take the advantage about the technology and used the technology to assist her in doing her professional job. The researcher argued the teacher realized that the technology integration made different atmosphere in the classroom, created an effective teaching which means the students easy to understand the teacher explanation and it is easy for the teacher to explain the lesson by using technology. The previous statement about teacher interview is described below:

(Teacher interview April 29 $9^{\text {th }}$ 2015)

$R$ : Teknologi apa yang ibu biasa gunakan dalam pengajaran ibu?

$\mathrm{R}$ : what kind of technology that sometimes you use in your teaching ?

T: Teknologi yang paling sering saya gunakan adalah penguunaan laptop, LCD, tape recorder, handphone, dan camera.

$\mathrm{T}$ : The technology that most frequently I used is laptop, LCD, tape recorder, handphone and camera

\section{b) Kinds of application or program used by the teacher}

The teacher was asked about the kinds of application or program that she used in teaching and learning process during teaching English. The answer indicated the various kinds of application used were power point presentation, audio player and prezi presentation. Application software (an application) is a set of computer programs designed to permit the user to perform a group of coordinated functions, tasks, or activities. Actually that program was not made for teaching but the teacher used and took advantage of the application for teaching. It was proved by the interview below. 
(Teacher interview April 29 2015 )

$R$ : aplikasi atau program apa yang ibu sering gunakan dalam mengajar?

$\mathrm{R}$ : What does the application or program that always you use in teaching?

T: Aplikasi yang sering digunakan dalam penggunaan laptop yaitu ppt, biasa juga saya gunakan audio prezi juga. Sesuatu yang baru bagi siswa.

T: The application I used is power point; sometimes I use audio and also prezi. It's a new thing for student.

\section{c) The Function of Technology}

The teacher was asked about the function of technology she used in her teaching. She argued that she created the different atmosphere to make the presentation unforgotten to her students. It was unusual atmosphere. Building up the students' motivation, the teacher considered the function of technology avoided boring. The teacher ensured that technology integration had its own function included creating something new for the teaching and learning process. It was proved in the conversation below;

(Teacher interview April 29 2015 )

R: Menurut ibu apakah fungsi dari penggunaan teknologi tersebut?

$R$ : What do you think about the function of the use of technology?

T: Tentunya dengan teknologi kita memberi kesan sesuatu yang baru kepada siswa, siswa itu bosan sehingga dengan teknologi itu mereka mendapatkan hal yang baru.

$T$ : Exactly by technology, we can give something new to the students; the students fell bored so by using technology they will get something new.

\section{d) The teacher's ways to teach by using technology.}

The teacher showed the way the teacher taught by using the technology. The teacher argued in teaching she used an application to help her present the material; she gave the example about the use of power point presentation. On that day she used picture to attract the student's attention and it made the students to be helped to understand material. It proved with the teacher's interview below;

(Teacher interview April 29 $9^{\text {th }}$ 2015)

$R$ : Bagaimana ibu mengajarkan materi menggunakan teknologi ?

$R$ : How do you teach the material using technology ? 
T: Tentunya dengan seumpama power point dengan gambar yang menarik akan membantu siswa untuk masuk dari materi yang akan diajarkan.

T: Exactly for example if we use power point by showing interesting picture it will help the student to understand the material taught well.

\section{e) The teacher's experience in achieving the technology used.}

The teacher was asked about how she achieved the skill in using the technology. The teacher ensured that there were some experiences had the teacher achieved in using the technology. She revealed that she had taken courses and many others ICT (Information and Communication Technology) Training. The teacher also had participated as the representative from SMAN 17 Makassar to join Australian Program. The teacher said that she was trained among a month in Australia about the use of technology as a source of learning in secondary senior high school. The previous statement about teacher interview was described below ;

(Teacher interview April 29 $9^{\text {th }}$ 2015)

$R$ : bagaimana ibu belajar penggunaan teknologi tersebut?

$R$ : How do you learn about the use of technology?

T: saya Pernah mengikuti Kursus, pelatihan website. ICT di Australia, program untuk partnership sekolah kebetulan pada saat itu saya ikut sebagai perwakilan untuk sekolah mewakili SMAN 17 untuk dilatih selama sebulan di Australia tentang penggunaan teknologi sebagai sumber belajar di tingkat Sekolah Menengah Atas.

$T$ : I have been taking course for that, I have joined website ICT workshop in Australia, the program for school partnership. Accidentally I joined that program as a delegation from SMAN17 to be trained for a month in Australia in term of the use of technology as a source of learning for secondary senior high school.

\section{2). Students' Response}

\section{a. Kinds of technology used}

The students were asked about the technology used by the teacher in teaching and learning process. The various program and application used by the teacher proved the teacher's knowledge and skill in using technology. The students were given the same question as noted below;

(Students interview April 30 ${ }^{\text {th }}$ 2015)

I: Apakah guru anda memanfaatkan teknologi dalam pengajaran?

I: does your teacher use technology in her teaching ? 
The students answers about the above question as followed;

Ya Speaker radio ppt untuk listening dan speaking (MAP: April 30 ${ }^{\text {th }}$, 2015)

Yes, speaker, radio, power point for listening and speaking

Email ,kamus elektronik, English translation (ZG: April 30 $\left.{ }^{\text {th }}, 2015\right)$

Email, electronic dictionary, English translation

LCD, PPT, internet, speaker (MFW: April 30 ${ }^{\text {th }}, 2015$ )

LCD, Power Point, internet, speaker

Based on the students interviews above the student gave the various technology which has ever been used by her teacher, from that information the researcher do really agreed that the teacher has enough knowledge and skill about the technology used.

\section{b. Availability and Accessibility of Computer Technology}

The researcher argued that the next aspect is Availability and Accessibility of Computer Technology. The process of technology integration is, in the first place, possible only with the availability of technology. The researcher believes that the whole process of technology integration cannot take off unless tools are available, although it is true that the availability of tools is not enough by itself to guarantee the effective process of technology integration.

\section{1) The technology facilitation provided in technology integration}

The researcher wanted to give limitation about the availability and accessibility of computer technology used by the teacher in teaching and learning process. To specify the real condition about the description of availability and accessibility in school based on the interview can be seen as follow;

(Teacher interview April 29 $9^{\text {th }}$ 2015)

$R$ : bagaimana tentang sarana yang disediakan disekolah seperti penyediaan computer dan fasilitas internet?

R:how about the facility prepared by school such as computer and internet accessibility?

T: kalau laptop, saya gunakan laptop sendiri kecuali yang semacam LCD tape recorder ada disediakan di sekolah. Disekolah ada wifi dan diperbolehkan untuk membawa alat komunikasi seperti smartphone tapi, ada kelas kontraknya dalam pembelajaran jika tidak diisinkan oleh guru yang bersangkutan tidak boleh digunakan. 
T: I prepared laptop by my own self except LCD projector, tape recorder, theywere prepared by school. At school it was wifi available and the students are allowed to bring communication device such as smartphone but, there is class contract, among the learning processes the students are not allowed to use it if the teacher doesn't permitted the students to use it.

Based on the teacher's interview above the researcher concluded that the school provided some facilities in integrating technology but the teacher's indicated that it was not enough to get the maximum result of technology integration. On the other hand the teacher's revealed that the minimum facilities couldn't stop her creativity to take the technology advantage in her teaching and learning process.

\section{c. Approach of integrating technology do teachers and students employ in learning and teaching}

One of the main focuses was to explain what and how technology integration took place in the classroom in learning and teaching processes and environments; that means how teachers were utilizing the available technologies in teaching and how students used them in learning. If we look at it in the broader perspective, the achievement of the national goals, as prescribed by the national policies and the institutional goals by the institutional policies, are anchored or achieved by the process in the classroom situations. Promoting efficient learning is the key objective or the central focus of integrating technology. Technology integration is a pedagogical strategy aimed at making the process of learning more efficient.

\section{1) Teacher's Response}

a) The teacher's ways in teaching English skills

The findings revealed the scarcity of equipment; especially the computer greatly affected and limited the strategies teachers used. For example, there are some strategies that teachers knew were good for learning but due to computer scarcity, they were not used. The teacher used technology to make easy for the student on paying attention and understand what the speaker talking about on the recording prepared by the teacher. The teacher was sure that the use of technology optimized the listening comprehension classroom. The following description can be seen in the interview with the teacher below;

(Teacher interview April 29 $9^{\text {th }}$ 2015)

$R$ : bagaiamana ibu mengajarkan 4 skill dalam bahasa inggris khususnya reading, writing, listening dan speaking menggunakan bantuan technology? 
R: how does the teacher deliver 4 skills in English especially reading, writing, listening, and speaking using technology?

T: Kalau Reading, saya meminta siswa untuk mencari sendiri untuk mereka, memberi tugas untuk narasi seperti cerita rakyat Sulawesi Selatan seperti cerita Malin Kundang saya buatkan ppt....menayangkan cerita-ceritanya. Kalau Listening, menggunakan tape recorder, laptop, biasa juga saya rekam kemudian perdengarkan keteman-temannya yang lain.

T: For reading, I have the students search the material their own, giving task to get narrative text like folktale from South Sulawesi or like Malin Kundang history that I have made in Power point Presentation ,... Showed the story. For listening, I use tape recorder, laptop, sometimes I record and then let them listened by their friends.

It was also noted in the syllabus that the teacher in SMAN 17 Makassar used multimedia in the particular skill such as listening comprehension and reading comprehension. The researcher also underlined that the listening comprehension would not run well if the teacher doesn't use or take the advantage of the technology.

\section{b) The use of social media in teaching and learning}

Before the researcher gave the explanation about the use of social media, the researcher underlined that the social media referred to any application design for communication and had it function to connect people by using text as the tools of communication. Such as facebook, twitter, path, instagram, line etc. in this case the teacher reported that some social media had it benefit but the teacher avoid the use of facebook, twitter, etc because there were so many content inappropriate provided by the social media. The teacher noted that the social media was avoided except email. the reason proved on the conversation below;

(Teacher interview April 29 $9^{\text {th }}$ 2015)

$R$ : kan sekarang sangat banyak siswa menggunakan media sosial seperrti FB, twitter, istagram, dsb. Apakah ibu memanfaatkan hal itu dalam pengajaran?

R: Now,there are so many students use social media such as facebook, twitter, istagram, etc. do you use the social media in your teaching?

T: oh...Social media, kalo saya untuk menghindari mereka terlalu fokus kepada fb saya samasekali tidak pernah, saya lebih memilih email. Apalagi dalam situasi belajar saya melarang meraka membuka fb. 
T: Oh...social media. Actually I avoid them focus on facebook, I never use it. I would rather to use email even in teaching learning process I forbid them to open facebook.

The teacher above had some various approaches use in her teaching on the particular skill. She has different approach for different skill taught. The teacher used internet provided by technology as searching engine to fulfill the material needed by the students, as we had known that there are a lot of reference that we can get from the internet.

\section{c) The reason of choosing E-mail}

The teacher was asked about the reason why the teacher preferred EMail to any other social media used in teaching English. The teacher emphasized that the use of any other social media like Facebook or Twitter bothered the students' concentration because there were many items which were not related to the lesson beside that. E-Mail had advantage and easy to access then the other social media. As noted by the teacher below;

\section{R: Boleh saya tahu alasannya kenapa lebih memilih Email?}

R: may I know the reason why did you choose Email?

T: itu karena Lebih simple lebih efektif, lebih mudah siswa untuk mengumpulkan. Mengindari jika ada yang lupa.

T: Because it was very simple, more effective, easier for students to collect, avoid if the students forget the task.

\section{d) The teacher's way to minimize the unexpected problem along the use of technology.}

The teacher was asked whether she faced the trouble or problem along the technology used. How the teacher avoid unexpected technology integration problems among the process of teaching and learning. The teacher assumed the problem solved based on the skill taught, the teacher gave the example when she taught listening comprehension. The script of sound had been printed so that if the electricity got in trouble or black out she could directly read the script that had been prepared by the teacher. The explanation before was proved below;

(Teacher interview April 29 $9^{\text {th }} 2015$ )

$R$ : Bagaimana cara ibu untuk meminimalisir hal yang tidak diharapkan terjadi dalam penggunaan teknologi seperti pada saat ibu mengajar tiba2 mati lampu?

$\mathrm{R}$ : How does the teacher minimize the unexpected problem along the use of technology for example the electricity off while you are presenting? 
T: $\quad$ kalau itu ada strategi khusus untuk menghindari masalah yang timbul dalam penggunaan teknologi, kalau listening saya sediakan skripya, atau menggunakan suara sendiri.

T: There was a strategy I have, to avoid the trouble in using technology, for listening I prepared the printed script or I use my own voice.

\section{2) Student's response}

\section{a) The technology influence toward students' motivation}

The researcher revealed the influence of technology in students' motivation based on the student's response.

The researcher also had students desire about the important of approach or strategy used by the teacher they all stated that use of teacher approach or strategy influenced the technology integration in teaching and learning process. Most of students agreed that the technology integration influenced their motivation. The students stated the use of technology and the teacher's approach was the perfect combination to motivate them in classroom, the students underlined that was very helpful to understand the lesson, the proved of the analysis before stated on the conversation below;

I: Menurut anda apakah strategi guru menggunakan teknologi berpengaruh terhadap motivasi belajar anda?

I: What do you think about the strategy used by the teacher?does it influence your motivation to learn?

Strategy guru berpengaruh terhadap motivasi kami. Sangat membantu contohnya kalau listening sangat membantu . (MAP: April $30^{\text {th }}, 2015$ )

The teacher's strategy influences our motivation. It is very helpful for example in listening it is very helpful.

Dengan pendekatan personalnya, mencoba membangun komunikasi dengan kita.(ZG: April 30 $\left.{ }^{\text {th }}, 2015\right)$

By her personal approach. She tried to develop communication with us.

Strategi guru sangat penting dalam penggunaan teknologi supaya kita tidak bosan, (RTS: April 30 ${ }^{\text {th }}$, 2015)

The teacher's strategy is very important in using technology so that we are not bored

Therefore (RTS) supported the important of strategies used by the teacher. She strongly stated that the use of technology didn't make the students got bored. 
On the other hand the (SDA) stated that the strategy used by the teacher developed the students enthusiastic in finishing assignment and it also gave interesting environment in teaching and learning process. (WOAK) revealed that the strategy was very influence the students' motivation but it depended on the teachers' way in conducting or gather the student in the class, the teachers' strategy in teaching had been the factor which influenced the students' motivation. The (AF) underlined that the more interest the technology used the higher interest of student in teaching and learning process. It made the strategy was needed by the teacher to be creative in designing the technology integration used to teach her students. On the line with (RA) argument (WOA) revealed that the students were really attracted and got spirit when the teacher conducted strategy teaching and learning process. Moreover the (MFW) had the same perception with (RA) about the important of strategy used to fulfill students' need in learning.

From the analysis above the all students described the important the teacher's strategy in motivating them and made them to be interesting in learning. The researcher was strongly agreed about the important of strategy used by the teacher in motivating student at accelerated program SMAN 17 Makassar.

\section{The teacher ways to maintain the motivation of students through integrated technology at accelerated program in Makassar senior secondary school.}

The researcher showed that she tried to design the technology use to attract the students' attention to the technology use. On that day the teacher used LCD projector and laptop as the devise and power point presentation as the application to help her to present the material. She showed the narrative text on the wall in front of the student. The presentation was completed by the paragraph and also the picture related the material presented by the teacher. The situation of the class became more serious all of the student eyes were on the wall presentation. They are very enthusiasm looking at the teacher explanation and the material presented.

\section{a. The reason of the importance of technology use}

The researcher explored the teacher's response of the important of technology. From this direct observation the researcher believed that there was significant different whether the teacher used the technology and without technology. The teacher also described the from interview as followed the conversation below; 
(Teacher interview April $29^{\text {th }}$ 2015)

$R$ : kenapa ibu mengatakan jika penggunaan technology disekolah itu sangat penting khususnya dalam pembelajaran?

R: Why did you say if the use of technology in school was very important especially in teaching?

T: Pernah siswa saya dalam proses pembelajaran bertanya kesalahseorang siswa yang tidak memperhatikan pekajaran saya. Eh kenapa kamu tidur? kemudian dia menjawab pada saat presentasi menggunakan computer saya termotivasi dan memperhatikan bu tapi setelah ibu mengajar secara biasa saya tiba2 tidak bersemngat, dari jawaban siswa itu saya sadar bahwa penggunaan technology itu sanngat penting,

$\mathrm{T}$ : Someday when in teaching and learning process I asked one of my students that were not looking at my lesson. Why did you sleep? Then he said to me that when you were presenting your material by using computer I am motivated and focus on your explanation mam but after that when you taught us as usual, I didn't have spirit anymore suddenly. From student argumentation I was aware that the use of technology is very important.

From the interview above the teacher was aware that there was positive effect caused by the technology used in her teaching and she revealed that the use of technology is very important in engaging students' motivation. The technology had been the tool of paying student's focus or attention in classroom

\section{b. The teacher's way of indicating and maintaining the students' motivation}

The teacher was asked about how the teacher indicated and maintained the student's motivation. The teacher revealed that if the the students were active in giving and asking question. It was an indication of the students' motivation. Then it was proved by the teacher's response below;

(Teacher interview April 29 $9^{\text {th }}$ 2015)

R: Bagaimana ibu mengetahu isiswa yang sedang termotivasi terhadap pelajaran dan baagiamana cara mempertahankan motivasi mereka?

T: ya siswa itu Merespon pertanyaan saya , monitor lansung, bagaimana mereka mengerjakan tugas 2 nya

The teacher tried to get closer to her students by walking around the class to know students' answer. There was a good teacher-student interaction appeared in the classroom. 
The teacher tried to control the students to maintain their motivation as noted in the researcher's field note.

\section{Students' response to the implementation of integrated technology in an accelerated program in motivating the students in Makassar senior secondary school.}

Generally accelerated programs students were positive about the use of technology in their learning. They stated they used computers in their day-to-day learning and indicated the presence of numerous benefits of using computers.

\section{a. Students' motivation}

The students were asked about their motivation if the teacher used the technology integration on teaching and learning process (MAP and MFW). Most of them said they were motivated when the teaching and learning process integrated the technology but some of them (S4 and S5) as the result of written interview using surveymongkey.com had different response, they revealed it depends on the lesson or the teacher's way in integrated the technology. This kind of case was supported by the student who was asked as followed;

I: Menurut anda apakah anda termotivasi jika guru menggunakan technology dalam pengajaran?

I: based on your mind, are you motivated if the teacher use technology in teaching?

Semangat belajar menjadi bertambah seiring dengan perkembangan teknologi yang merambat dalam bidang pendidikan. Dengan bertambahnya semangat maka motivasi dan keinginan belajar menjadi bertambah. (MFW: April $30^{\text {th }}, 2015$ )

My spirit increase along the development of technology which is separated in Education. By the increasing of spirit so the motivation and desire to learn become increases

Tergantung pelajarannya. Kalau pelajarannya seru, saya akan bertanya sedetail mungkin mengenai tugas atau pr atau materi yang diberikan. Tapi kalau pelajarannya saya tidak suka, saya cenderung malas-malasan dan tidak peduli (S4: surveymongkey.com June $26^{\text {th }} 2015$ )

Depends on the lesson, if the lesson is interesting I will ask about the task in detail or the lesson given. But if the lesson I don't like I will be lazy and do not care of. 


\section{b. Students reason of their motivation}

In this case the students were aked about their reason of being motivated on technology integration conducted by the teacher, the finding showed the benefits that they indicated included the technology facilitates better learning, helps them in solving many problems, helps to learn easily, makes learning interesting, makes learning more interactive, gives access to different resources of knowledge and to a lot of information, saves time, gives access to current and up-to-date information, and helps in an easy search for learning materials. The benefit of technology helping in searching for materials or information recurred more frequently than other benefits, suggesting that students use computers more for searching for information on the Internet

I: Menurut anda hal apa saja yang membuat anda lebih termotivasi ketika guru menggunakan teknologi dalam pembelajarannya?

I: what does make you be more motivated when you teacher used technology in teaching?

Guru Lebih sering berinteraksi dengan siswa. (S2: surveymongkey.com June $26^{\text {th }} 2015$ )

The teacher often interact with the students

Presentasi yang lebih berwarna danlebih singkat membuat kami lebih mudah mengingat dan lebih tertarik untuk belajar.(S8: surveymongkey.com June $26^{\text {th }} 2015$ )

The presentation become more colorful and more efficient make us easier and more interested in learning.

Termotivasi karena presentasi guru yang biasanya menarik. Materinya yang up to date beserta contohnya. (S18: surveymongkey.com June $26^{\text {th }} 2015$ )

Being motivated because the teacher presentation is interesting. The material is up to date by giving example.

\section{c. Students response when they were motivated}

In this case the researcher gave the students the same question about the students' response when they were motivated. Based on the answer from the student we can see that two of them will be active in teaching and learning process (MAP and WOAK), three students will ask the question as their response when they were motivated MAP, MFW, MOA), and most of all students stated that they were enthusiastic and paid their attention to the lesson or material delivered by the teacher. 
The researcher argued that there were various ways to response the technology integrated but in accelerated program they prefer to be enthusiastic and paid attention to the lesson when they were motivated The interview with the student about their response to the implementation of integrated technology can be seen below;

Question

I: Apa yang anda lakukan ketika anda merasa termotivasi pada saat pembelajaran?

I: what do you do if u feels motivated when you learn?

The question was addressed to the students to get the description about the students in accelerated program response to the integrated technology used by her teacher based on direct information from students.

Cara menunjukkan kalau saya termotivasi lebih antusias untuk bertanya, perhatikan materinya,(MFW: April $\left.30^{\text {th }}, 2015\right)$

The ways to show that I am motivated are enthusiastic for asking question and paid attention to the material

Aktifantusias, membuat teman2 yang lain juga termotivasi. Focus terhadap materi yang dibawakan oleh ibu. (WOAK: April $\left.30^{\text {th }}, 2015\right)$

Active, enthusiastic, get friends to be motivated. Focus on the material deliverd by the teacher.

Saya akan lebih memperhatiakan pelajarannya dan jika ada yang saya tidak mengerti maka saya akan lansung bertanya. (MOA April $30^{\text {th }}, 2015$ )

I will pay attention to the lesson and if there something I don't understand I will directly ask for question.

\section{DISCUSSION}

The researcher described that there are three aspects included in the implementation of integrated technology. They are the knowledge and skills of computer use, availability and accessibility of computer technology, and the approach of integrating technology teachers and students employ in learning and teaching. The research shows that the teacher ways to motivate and to maintain the student's motivation, the teacher's ways to build up the student's motivation and make them to be maintained during the class deeply. The research shows that she tried to design the technology use to attract the students' attention. Leak and Pachler (1999) say that the attitudes of the teachers toward technology is very important in determining how much teachers are willing to learn and use computers with their students. 
Teachers should be enthusiastic about using technology, and students should be excited about their level of accomplishment in using computers. The building of positive attitudes begins with the realization of the value of using computers. For example, teachers should realize how the use of technology could reduce the stress of facilitating the process of learning. The data from the research shows the students' responses to the implementation of integrated technology in an accelerated program in motivating the students in Makassar senior secondary school. It is generally described that accelerated programs students were positive about the use of technology in their learning.

\section{CONCLUSION}

The conclusion of this research consists of three points. First, based on teacher and students interview, integrated technology has been implemented at accelerated program at SMAN 17 Makassar. It was shown that the teacher has enough knowledge and skill of technology used, the school was available and accessible of technology used, and the teacher had her own approach and strategies to cover the technology integration implemented on the accelerated program. Second, based on the teacher and students interview, design the technology made by the teacher use to attract the students' attention and the teacher's way to gather the student in process of teaching and learning motivated the student in learning, the teacher gathered the students make the students pay attention and became enthusiastic to the lesson.

Third, accelerated programs students had positive response about the use of technology integration in their learning. The benefits that they indicated included the technology facilitates better learning, helps them in solving many problems, helps to learn easily, makes learning interesting, makes learning more interactive, gives access to different resources of knowledge and to a lot of information, saves time, gives access to current and up-to-date information, and helps in an easy search for learning materials. 


\section{REFERENCES}

Boyd, Drick. 2005. Effective Teaching in Accelerated Learning Programs. Eastern University: an Social article journal. Retrieved in 2005.

Creswell, J. W., \& Miller. 2000. Determining validity in qualitative inquiry. Theory into Practice, 39(3), 124-131.

Dornyei, Z. 2001. Teaching and Researching Motivation.Longman: Pearson Education Limited.

Eggen P, Kauchak D. 2002. Strategies for teachers: Teaching content and thinking skills (4th ed.).Needham Heights: M.A. Allyn and Bacon.

Fredericks, J. A., Blumenfeld, P. C., \& Paris, A. H. (2004). School engagement: Potential of the concept, state of the evidence. Review of Educational Research, 74, 59 - 109.

Harmer, J. 2001. The Practice of English Language Teaching, London: Pearson Education Limited. ISBN: 0582 403855, 45

Leak, M., \&Pachler, N. 1999. Learning to teach using ICT in secondary schools. New York: Routledge.

National Forum on Educational Statistics (NFES). 1998.Technology in schools, Suggestions, tool and guidelines for assessing technology in elementary and secondary education.Retrieved on February 20, 2006, from http://nces.ed.gov/pubs2003/tech schools/chapter7.asp.

Patton, M. 2002. Qualitative Research Practice: A Guide for social science students and researchers. Newbury Park, CA: SAGE Publications.

Umayanti, Uum. 2012. The influence of the application of prequestioning on Reading comprehension at SMK Gracika Cirebon. State Institute for Islamic Studies. Cirebon

Weston, T. 2004. Formative evaluation for implementation: Evaluating educational technology application and lessons. American Journal of Evaluation, 25(1), 51- 64. 